\title{
Overviewing Hardiness Toward Self-Employed People With Diffabilities in Yogyakarta
}

\author{
$1^{\text {st }}$ Abdu Alifah* \\ Psychology Department \\ Faculty of Social Sciences and Humanities \\ State Islamic University Sunan Kalijaga \\ Yogyakarta, Indonesia \\ abdualifah96@gmail.com
}

\author{
$2^{\text {nd }}$ Mayreyna Nurwardani \\ Psychology Department \\ Faculty of Social Sciences and Humanities \\ State Islamic University Sunan Kalijaga \\ Yogyakarta, Indonesia \\ psikologijogja@yahoo.co.id
}

\begin{abstract}
Hardiness is a character that influences on how self-employed diffables view their stress and determine an effective response. This study aimed to explore the hardiness of self-employed diffables in Yogyakarta with phenomenological method that used an interview, observation and documentation in collecting data of research. The Subjects of this study were two diffables with physical disabilities (polio) and blind person who started their businesses for more than three years and the business were being maintained well until the time of study. The results showed that hardiness played an important role toward self-employed diffables with certain disabilities in dealing with stressful events while running their businesses. Hardiness enables self-employed diffables to use effective coping strategies in solving various problems and to keep a good commitment in maintaining their own business, positive perception towards problems, and optimistically developing their own business in the future.
\end{abstract}

Keywords—diffables, hardiness, self-employed

\section{INTRODUCTION}

The term 'diffable' consisted of two words, namely 'dif-' which mean 'different' and 'able'. It considered as a new term that showed more humanism and reduced discriminatory elements [21]. However, according to Kusumaningrum, et al., [10] currently a lot of diffables were being discriminated, underestimated and regarded as an inferior by society. The diffables were being considered as individuals who unable to work, educate, study, ride the transportation, or even to live independently and always need help from other people.

One of the discriminations experienced by the diffables is job availability. In Special Region of Yogyakarta (DIY) province, the fact showed only a few of the diffables who work in several companies. According to the data which are published by the Department of Manpower and Transmigration (Disnakertrans) DIY in 2018, the number of diffable workers in DIY are 153 people that spreaded in 35 companies. Whereas in 2018, there were 4,569 companies in DIY [27]. This gap will be more ironic considering there are 29,530 numbers of diffable in Yogyakarta (Social Service of Special Region of Yogyakarta).

Highlighting this issue, Purwanta as chairman of the Committee for Protection and Fulfillment of Diffable Right (PPHPD DIY) said that many diffables in Yogyakarta were forced to be self-employed and open their own businesses to survive (move on to informal sector). Nonetheless, diffable who decided to be self-employed also suffered several difficulties and impediments such as unfriendly access for diffable (Prakoso, 2016). In fact, there are diffables who had been suffering discrimination, such as Parjan (blind person) and Erni (person with polio), some self- street vendors in Yogyakarta and were arrested by SatPol PP because considered as beggars and were imprisoned for 13 days [26].

Although suffered from various kinds of difficulties and impediments, there were several diffables in Yogyakarta who are able to survive and even show their development and progress in self-employment such as TY- a diffable who founded a Difa Bike and TW- a diffable who founded massage parlor. Based on the result of preliminary study through observation and interview, researchers found that both of them experienced some difficulties while running their business such as stigma, persecution and theft experience, difficulties in transportation, finance, as well as other technical problems. But, both of the informants remain in maintaining their business with all those difficult conditions. They were able to deal with stresses, especially while running their business activities. According to Kobasa [9], an individual's ability to successfully cope with stress and remain healthy was defined as "Hardiness".

\section{A. Hardiness}

According to Kobasa [9], "hardiness is a personality construct composed of three traits-control, commitment, and challenge-that may influence both cognitive appraisal and behavior in response to stressful events". Meanwhile, according to Maddi [12], [13], [14], [15] "hardiness has emerged in psychology as a pattern of attitudes that facilitates turning stressful circumstances from potential disasters into growth opportunities". Hardiness is associated with enhanced performance and mental health of a person in dealing with stress [12], [13], [14], [15]. Moreover, hardiness is constituted by $3 \mathrm{Cs}$ as control, commitment, and challenge [9],

Maddi \& Kobasa (1984) explained that individuals with a good control always believe and act as if they are able to influence the events around themselves, they try to change a 
difficult situation into a good situation, view events in-depth perspective, and be optimistic in dealing with problems. Meanwhile, individuals with strong commitment are often easier to get involved in work, do everything whole-heartedly and make themselves stronger in stressful situation. Individuals with good commitment will use coping strategies that are appropriate with their own values, goals and abilities to deal with stressful situations (Maddi \& Kobasa, 1984).

Furthermore, Maddi \& Kobasa (1984) said that individuals who like a challenge will always consider that the changes occurred in life as something useful. They tend to feel that challenges, rather than stabilities, as the normal mode of life and constitutes motivational opportunities for personal growth rather than threat to security. These three aspects of hardiness, according to Maddi \& Kobasa (1984) are integrated and influencing one another. In the other contexts, researchers also argue that there are several factors that influence hardiness such as social support (Maddi, 2002), parenting (Maddi, 2002), self-confidence and positive self-image (Warner, 1998 as cited in Heriyanto 2011), and mastery of experience (Bissonete, 1998).

\section{B. Self-Employed}

This research used the term self-employed instead of entrepreneur. Indeed, there are two terms that are often used, namely entrepreneurship and self-employment (Gilkerson \& Paauwe, 2003). In the context of diffable, it's more appropriated to use the term "self-employed" that are defined as people who found, owned and managed business under their own responsibility which mostly consisted of small companies (Gilkerson \& Paauwe as cited in Caliendo, et al, 2011). The differences between both of them are that the scale of entrepreneurship generally bigger and responsibilities heavier than those of self-employed.

Gilkerson \& Paauwe (2003, as cited in Caliendo et al., 2011) emphasized that self-employed refers to people who participate as own-account workers or workers who have their own money, pay themselves, work for themselves and commonly may not employ others, or refers to business owners who employ other people in small scale. This term obviously different from an entrepreneur, although according to Kiyosaki (2001), “a successful entrepreneur generally started his career as a self-employed and that was the reason why people equalized the two of them". Another fundamental difference between an entrepreneur and self-employed is that entrepreneur has a long-term vision in forming business system that is able to continue without the presence of an entrepreneur (Purwanta, et al., 2016). In the end, researchers focus on the discussion of diffable who are conducting selfemployment.

\section{METHOD}

This research used qualitative-phenomenology method to capture meaning from the experience of human life. Phenomenology research strategy identifies the nature of human experience about a particular phenomenon (Creswell,
2013). Phenomenology explains the phenomenon and its meaning for individuals by conducting interviews with a number of individuals. According to Cresswell (2013), "phenomenological research usually ended by concluding the essence of meaning".

\section{A. Subject}

the Subjects of this study were two diffables with physical disabilities (polio) and blind person (congenital), male, aged around 15-60 years old (productive age), had their own business for a minimum of three years, and stayed in Yogyakarta. This study used snowball sampling method in which of each sample was recommended by previous people according to the criteria of subject.

\section{B. Data Collection Methods}

This study used an interview, observation and documentation in collecting data of research. This study used semi-structured interview which was part of in-depth interview category. The purpose of semi-structured interview was to explore problems more overtly (Sugiyono, 2008). The observation used in this study was a non-participant observation. In this case, researchers came, saw, and paid attention to subject activities in a certain time, without getting involved with those activities (Affifudin \& Saebani, 2009). The documentation techniques used in this study include news related to informants and their business, a few images on their social media, their business websites, as well as the pictures that researchers photographed directly.

\section{Data Analysis Methods and Validity}

The method of data analysis of this study used the analysis method form Patton (1994, as cited in Poerwandi, 1998) that consisted such steps. First, organizing of data. The researchers read the narrative that has been transcribed carefully and conscientiously then grouped the data. Second, coding of data. The researchers numbered each line then proceeded them with coding. The code is given behind the subject's answer. In this phase, the researchers did not change the essence of the sentence spoken by the subject. The third, interpretation and discussion. The researchers correlated the narrative with a theoretical framework. Then write the analysis of research into narrative form.

Meanwhile, the validity of this study used two techniques, such as the technique of checking credibility and confirmability. The credibility test used in this study was triangulation method. The researchers checked and compared the result of interviews between subjects and significant others as well as among another supporting data collection methods such as observation and documentation. Confirmability was conducted by discussing the results of research with experts in order to get professional judgment. In this study, the result of study were audited by a supervisor who is considered as an expert in performing the conformability. 


\section{RESULT}

The results of this study are based on the findings of each informant. The results are described based on the informant's profile, informant's self-employment proses, informant's selfemployment problems, aspects of informant's hardiness during self-employment and factors that influenced informant's hardiness. The description of each informant as follows:

\section{A. Informant $T Y$}

Informant was born in Solo. Informant was the first child of two siblings. Informant finished his study as bachelor or udergraduate in agricultural program at Sebelas Maret University (UNS), Solo. Informant grew up in entrepreneurial family environment. Informant's mother and grandmother were traders. Since childhood, informant has been following his mother who sold some stuff in traditional market. Informant has been educated to be a hard worker. Informant claimed that he never aspired to become an employee in any company and preferred to be a self-employed in animal husbandry.

Informant started his first business when he was a student in college, specifically at second term. Informant was selling clothes, graduation mementos, invitation letters or tree-seeds and other types of plants. The purpose of informant in being self-employed at that time was only for gaining daily extra income and training to improve his business skill.

The first company that was found by informant was farm development \& maintenance. In the other side, informant also had his own farm. Informant owned two farms consisting of cow and chicken. In the first year, informant had succeeded in achieving the profit around 300 million (rupiah). In 2009, informant's company transformed form $\mathrm{CV}$ into a corporation (PT-Perseroan Terbatas) that covered many subsidiaries. At that time, informant was able to sell 25 cows on average per day. In 2011, the informant reached to the peak of his selfemployment journey which marked by his achievement of possessing 80,000 chickens. However, in 2012 his chicken farm business was unstable and began to collapse. This failure have left a lot of debts and finally forced him to sell all of his assets including land, houses and so on.

There were some problems that faced by informant while running his business, such as the difficulties in educating the drivers because mostly the drivers are less educated (only elementary school graduate or had no school experience at all), some driver had low IQ level (below average)-even some of them had a mental retardation, the difficulties in cracking down on drivers firmly because their psychological and mental conditions are prone to depression, drivers who had always other activities outside of work, the rhythm of the driver's performance that didn't achieved the target, the road terrain that was not appropriate with transportation they used, and looked for funds to cover operational costs that made informant often stressful. In addition, there are other problems that confirmed by significant other (AW) like scrambling the customer among drivers, driver's family problems issues and others.

In solving the problems that occurred during selfemployment, informant viewed them as something that must be resolved immediately. Informant believe that he was able to solve the problems he faced, even though those problems didn't have to be solved immediately. However, informant experienced the stress when faced a lot of problems, especially in financial problems and drivers. Informant usually dealt with stress by hanging out while trying to look for solutions in solving the problems. In addition, informant extremely believe that Difa Bike would eventually develop.

In addition to the fact that informant was educated in an entrepreneurial family with full of independence and hard work since his childhood, informant's hardiness during his self-employment is also influenced externally by social support that gained from his families, prospective wives, colleagues, drivers, and society around himself that often helped Difa Bike. Significant others (AW) said that informant has good and positive relationship with his family and people around him, even they always help each other in daily life.

Meanwhile, internally informant has a high selfconfidence which was trained since he was studied in college by joining various student organizations such as BEM (Badan Eksekutif Mahasiswa), HMJ (Himpunan Mahasiswa Jurusan) and Teater community (UKM-Unit Kegiatan Mahasiswa). In addition, informant also has a positive self-image. This is shown by, for example, the view of informant towards himself. Informant believed that he has no disability although, in fact, he possessed a polio.

\section{B. Informant $T W$}

Informant came from Boyolali, Central Java, but currently live in Yogyakarta. Informant has been living in Yogyakarta since high school until now. Informant was diffable with blind who currently works as a massage therapist and has a massage parlor named Triwibowo Terapis Nusantara, which are founded in 2016.

Informant said that becoming a self-employed was his own desire. Self-employed was one of his dream besides being a professor and a physician. Furthermore, informant's motive to be self-employed was to spread benefit for society around himself, beside covering financial needs and developing employment opportunities for diffables. In addition, informant also wanted to prove that such diffables like him could live independently.

Informant started his first self-employment in high school. The first product he sold at that time was 'Mister Juicy'. Informant claimed that his aim to start being a self-employed was only for dabbling. While, in addition, informant also worked part-time at Atmajaya University as an operator at beverage shop. Furthermore, informant sold variety of goods such as perfume, snacks, credit (for prepay), also massage parlor service. Informant started developing his business in 
massage parlor service professionally in 2016 after completing some certification in professional massage training.

When he was student in college, informant not only tries to develop his massage parlor, but also tries to improve himself, mainly in exploring his business skill by following the Student Organization (KOPMA-Koperasi Mahasiswa) at his campus. Although at that time, according to informant, he received some discriminatory treatment as diffable such as a negative stigma and exiled during the activities.

In the process of undertaking his business, informant experienced a various kinds of difficulties and impediment such as being rejected by the community because considered as a beggar, negative stigma of society that hesitated in viewing such diffable like him being self-employed, constrained on human resource issues and have no co-worker, difficulty in finding transportation every time informant got some call to massage outside parlors, often not paid by his own consumers, experienced theft and persecution by person who take an advantage of his disability.

Informant run his massage parlor based on desire to help another and sincerity. Informant loved his massage parlor business. For informant, massaging was his passion. Informant considered his work (as a therapist massage) as one of the noble works in Islam. Significant others (DK) confirmed that, based on public opinion in response to informant, he (informant) and his massage parlor have significant impact to the society because many people need his help.

Furthermore, informant hardiness was influenced externally by parenting style that educated him to behave like a normal people (non-diffable). This parenting style, affect him in the future, that indicated by informant's positive selfimage in viewing himself as a better. Informant also got some social support from his family and his close friends. Meanwhile internally, informant had a good self-confidence. He felt that he had been needed by people around himself. In addition, informant also had positive self-image as diffables. He believed that he can be as successful as normal people. Informant also preferred to be treated normally rather than pitied.

\section{DISCUSSION}

Self-employment was an individual who create new business by taking risks and challenges to achieve significant profits and growth by calculating and increasing resources optimally (Scarborough et al., 2006 as cited in Slamet et al., 2014). According to Kitching (2014) there were two main factors that made individuals to be self-employed, namely the pull factor such as freedom in creation, independence, desire, profit and others, as well as push factors such as being unemployment, bored in being an employee, employee discrimination and others.

Informant TY as well as informant TW wanted to be selfemployed from the very start and decided to be self-employed on their own desires. Even for the two informants, self- employment was their dream. From the very start of entering in agricultural science at Sebelas Maret University, Informant TY didn't plan to be a worker in any company at agriculture sector, but wanted to be self-employed in animal husbandry. For informants TW, self-employed was one of his dream besides to be a professor and a physician. Although in fact, informant TW used to apply for civil servant and failed because there was no allowance for diffable (blind). Therefore, not only pull factor that caused informant TW to be selfemployed, but also push factor.

Two informants had different goals when starting their own business. Informant TY said that his purpose in being self-employed at that time was only for gaining daily extra income and training in improving his business skill. Meanwhile, informant TW claimed that his aim to start being a self-employed was only for dabbling. However, after passed a variety of experiences and a long process of selfemployment, both of informants changed their purpose. The two informants set new goals, namely to provide benefits for others, especially for diffables, as well as their desire to open up employment opportunities and empower them. This was similar with Suryana (2013), who said that one of selfemployed goals was to realize the advancement and society welfare.

During self-employment process from the beginning until now, the informants had certainly faced different difficulties and impediments to each-others. The difficulties and impediment that informant TY experienced in his selfemployment mostly relating to human resources (HR) and technical issues that not appropriated to the concepts and systems on reality happened. Meanwhile, informant TW faced more various problem in the process of self-employment such as being rejected by the community because considered as a beggar, negative stigma of society that hesitated in viewing such diffable like him to be self-employed, constrained on human resource issues and have no co-worker, difficulty in transportation, or even experienced certain criminalization such as theft and persecution.

According to Boyd and Gumpert (2002, as cited in Lubis, 2014), one of the cause that make a self-employed stressed was human resources issue. In this case, each informant got the problem in human resource issue. In addition, informant TY also claimed that another one that made him stressful was financial problems as well as informant TW got frustrated and almost closed his businesses while facing financial problems after experienced extortion and persecution. This problem, according to Lubis (2014), indeed was one of the risks that certainly would be faced by all those who are involved in selfemployment.

Apart from all of those difficulties and impediments they experienced during self-employment process, in fact this two informants had been surviving and even developing continuously their business. This reality clearly showed that both informants have a tremendous hardiness. According to Maddi (2002), hardiness has emerged in psychology as a 
pattern of attitudes that facilitates turning stressful circumstances from potential disasters into growth opportunities (Maddi, 1994, 1998, 2002, 2006). Meanwhile, Kobasa (1979) said that hardiness is defined in terms of more specific dimensions of control, commitment and challenge characteristics that may influence both cognitive appraisal and behavior in response to stressful events.

In viewing control aspect of informants, both of them used the problem focus coping strategy while dealing with problems in self-employment. Informant TY would try to solve the problem as soon as possible to avoid protracted. While informant TW tried to deal with these problems vigorously. Both informants also admitted that they would ask for help to others in solving the problem. Informant TY often asked for help to one understood the condition of the driver which were being in trouble. While informant TW claimed that he would ask for help to his mother or people around himself. Informants optimistically believed that they could solve problems and looked at the problem in-depth. Informant TY had a strong belief that God will always be there in every difficult situation that he faced. Informant believed the problem that struck him as a life experience that should be learned and was an examination that given by God to raise his life degree. Meanwhile, informant TY extremely believed that Difa Bike would eventually develop.

Then, in viewing aspect of commitment, the two informants showed their commitment differently. Informant TY totality dedicated in developing Difa Bike which was oriented as social entrepreneur for diffable. Informant TY felt an enjoyment with his Difa Bike business and was very happy as well as proud of Difa Bike. Informants TY also often accompanied and directed the drivers with full of patience as well as tried to assist them in completing their problem. Informant TY has promised himself to continue in educated and guiding the drivers until the end of his life. In the other side, informant TW run his massage parlor based on desire to help another and sincerity. Informant loved his massage parlor business. For informant TW, massaging was his passion. Informant TW considered his work as a physician or therapist (massage) was one of the noble works in Islam. All of those commitments that belong to the two informants were caused by reason. The strong commitment that belonged to informant TY in developing Difa Bike was based on informant own experience as a diffable that faced many difficulties and discrimination. While the commitment of informant TW was based on belief that work as a physician or therapist (massage) was one of the noble works in Islam.

The challenge aspect of each informant could be seen through two stuffs. First, how did informants perceive the problem. In this case, the two informants tended to improve a good challenge character in spite of having different perspectives on an issue. Informant TY viewed the problems occurred differently is not as a problem anymore, it's just a matter on how he handled appropriately. Informant TY perceived the problem of life as a valuable experience that should to be learned for the future life. Meanwhile, informant TW interpreted the difficulties and impediments that he faced by analogizing like philosophy of coffee. Like an aroma of coffee, informant TW argued that individual's best ability would appear while one was under tremendous pressure situations.

Second, how did informants anticipated changes that occur as a stimulus to develop. Each informant already planned and set strategies in viewing the challenges. According to the informant TY, the problem of disability in a wide context would never and may be would be more complex. However, informant considers this uncertainty as a challenge for Difa Bike to continue developing as a system that solved disability problem. For this reason, the informant planned to expand his business by creating Difa Car and a Digital Center for diffable. Meanwhile, in viewing the challenges of competing massage parlor business now days, informant TW planned in creating a legal corporation to distinguish his massage parlor with another as well as creating another business like honey shop.

Furthermore, Maddi (2002) stated several factors that could affect a hardiness were social support and parenting style. Informant TY has been educated by his mothers to be an independent individual and hard worker. Informant has been educated by his parents to behave like other normal people (non-diffable). Parenting style received since childhood made informants developed a positive self-image and high selfconfidence. As explained by Warner (1998, as cited in Heriyanto 2011), individuals who have self-confidence and positive self-image would have good self-control, more optimistic, and would be avoided from possibility of being stressed. Aside from that, high self-esteem affected informant's control and challenge. This was a reason that why informants believed they were able to solve problems and optimistic in developing their business.

Informants also often got such help from others in solving their own problem. Informant TY received social support from parents, wives, staff and drivers and other people around himself. While informant TW often got his social support from his mothers, his uncle, aunt and her child as well as his closest friends. This was associated on what stated by Maddi (2002) that social support has a significant relationship with hardiness. If individual has good social support, the hardiness will increase.

Meanwhile, Bissonete (1998) said mastery of experience showed that individuals owned the skills needed to succeed and ultimately would be able to increase hardiness. In this case, the two informants had a lot of experience in being as self-employment. The failure experience in the past made informant TY felt that he was ready enough to face problem today. Informant TW have a lot of difficult experiences that he faced during his self-employment process. All of those made informants viewed that all problem as valuable lesson for moving forward. 


\section{A. Conclusion}

Self-employment was a difficult activity, especially for diffables who have certain physical limitations. In this study, self-employed diffables often faced difficulties during running their businesses, such as negative stigma, persecution and theft experience, difficulties in transportation, finance, and other technical problems. These difficult situations made them stressed, even frustrated and almost closed their businesses. In the other side, the fact showed that diffable had been surviving in maintaining their business and sustainably growing. Hardiness enabled them to deal with difficult situations. This hardiness was reflected in three aspects. First, control. The diffables had a good control in solving problems by using appropriate and effective coping strategies. Second, commitment. The diffables also had a strong commitment that appointed on how they had been conducting their own business in totality, earnest, diligent and full of love. The last, challenges. This challenge could be viewed through their positive perceptions towards problems and optimism in developing their business sustainably.

The hardiness on self-employed diffables was influenced by several factors such as parenting style, namely independent, hard work, and behaving normally, social support obtained from family, friends and those closest to them, self-confidence in ability to solve problems, positive self-image such as being dependable, diligent and enthusiastic, mastery of experience in self-employment process, empathy for others diffables, and the last is religiosity.

\section{B. Recommendation}

The next researchers expected to discover disabilities issue through another psychological perspective such as selfconcept, motivation, or self-employment decisions. In addition, the next researcher also expected to consider diversity in determining the sex on criteria of informant regarding that the informants in this research only consisted of male.

\section{REFERENCES}

[1] Bissonnette, M, "Optimism, hardiness, and resiliency: a review of the literature. Prepared for the child and family partnership project. Southern Online Journal of Nursing Research, vol. 09 (04), 1998, pp. 2-16.

[2] Caliendo, M., Fossen, F., \& Kritikos, A. S, "Personality characteristics and the decisions to become and stay self-employed" Small Business Economics, vol. 42 (4), 2014, pp. 787-814

[3] Creswell, J. Research design, pendekatan kualitatif dan mixed edisi 3. Yogyakarta, 2013.

[4] Gilkerson, L. D., \& Paauwe, T. M, "Self-employment: from dream to reality: an interactive workbook for starting your small business. JIST Works, 2003.

[5] Hasbiansyah, O, "Pendekatan fenomenologi: pengantar praktik penelitian dalam ilmu sosial dan komunikasi," Jurnal Komunikasi, Vol. 9 (1), 2008, pp. 163-180.

[6] Heriyanto, Y. Hardiness Pada Penderita Jantung Koroner (Studi Deskriptif Kuantitatif di Purwokerto). Dissertation. Purwokerto, Faculty od Psychology, University of Muhammadiyah Purwokerto, 2011.

[7] Kitching, J, "Entrepreneurship and self-employment by people with disabilities," Background Paper for the OECD Project on Inclusive Entrepreneurship. Kingston University, 2014.
[8] Kiyosaki, R. T., \& Lechter, S. L, "The cashflow quadrant: panduan ayah kaya menuju kebebasan finansial," Jakarta, Gramedia Pustaka Utama, 2001.

[9] Kobasa, S, "Stressful life events, personality, and health: An inquiry into hardiness," Journal of Personality and Social Psychology, Vol. 37 (1), 1979, pp. 1-11.

[10] Kusumaningrum, D. N., Afina, O., Agustin, R. A., \& Herwiandini, M., "Pengaruh asean disability forum terhadap pengembangan ekonomi penyandang disabilitas di indonesia," Insignia Journal of International Relations, Vol. 4 (01), 2017, pp. 13-26.

[11] Lubis, S. B.,"Kewirausahaan" Universitas Terbuka, Vol. 1, No. 338.04, 2014, pp. 1-32.

[12] Maddi, S. R., "The story of hardiness: Twenty years of theorizing, research, and practice. Consulting Psychology Journal: Practice and Research, Vol. 54 (3), 2002, pp. 173.

[13] Maddi, S. R., "Hardiness: The courage to be resilient," Comprehensive handbook of personality and psychopathology, 2006, no. 306.

[14] Maddi, S. R. Hardiness: The courage to grow from stresses. The Journal of Positive Psychology, Vol. 1 (3), 2006, pp. 160-168.

[15] Maddi, S. R., "Relevance of hardiness assessment and training to the military context," Military Psychology, Vol. 19 (1), 2007, pp. 61-70.

[16] Maddi, S. R., \& Harvey, R. H., "Hardiness considered across cultures. In Handbook of multicultural perspectives on stress and coping," Springer, Boston, MA. 2006, pp. 409-426.

[17] Maddi, S. R., Khoshaba, D. M., Harvey, R. H., Fazel, M., \& Resurreccion, N., "The personality construct of hardiness: Relationships with the construction of existential meaning in life," Journal of Humanistic Psychology, Vol. 51 (3), 2011, pp. 369-388.

[18] Maddi, S. R., Matthews, M. D., Kelly, D. R., Villarreal, B., \& White, M., "The role of hardiness and grit in predicting performance and retention of USMA cadets," Military Psychology, Vol. 24 (1), 012, 2012, pp. 19-28.

[19] Poerwandi, E. Kristi., Pendekatan kualitatif dalam penelitian psikologi," Jakarta: LPSP3 UI, 1999

[20] Purwanta, E., Hermanto, H., \& Harahap, F., "Analisis kebutuhan untuk berwirausaha pada siswa berkebutuhan khusus," Cakrawala Pendidikan, 2016.

[21] Ramadhan, M \& Suryaningrum, C., "Adversity quotient ditinjau dari orientasi locus of control pada individu difabel," Jurnal Ilmiah Psikologi Terapan, 2012.

[22] Slamet, F., Tunjungsari H. K., \& Le, M., "Dasar-dasar kewirausahaan: teori dan praktik," Jakarta: Pemata Putri Media, 2014.

[23] Sugiyono, "Metode penelitian kuantitatif, kualitatif, dan R\&D," Bandung: Alfabeta, 2008.

[24] Suryana, S. Kewirausahaan: Kiat dan Proses menuju Sukses. Jakarta: Salemba Empat, 2014.

[25] Prakoso, S. T., PEKERJA DIFABEL : Kuota Pekerjaan PNS \& Swasta Masih Jauh Dari Harapan. Harian Jogja. 2016. Link: https://jogjapolitan.harianjogja.com/read/2016/05/19/510/720840/pe kerja-difabel-kuota-pekerjaan-pns-swasta-masih-jauh-dari-harapan

[26] Sis \& Irawan, I. K. Hebatnya Pasangan Disabilitas Asal Yogya Ini, Mereka Pantang Ngemis dan Pilih Keliling Jualan Roti. Tribun Jogja. 2017. Link:

https://jogja.tribunnews.com/2017/07/14/hebatnya-pasangan-disabilitasasal-yogya-ini-mereka-pantang-ngemis-dan-pilih-keliling-jualan-roti

[27] Ridarineni, N \& Assidiq, Y. Perusahaan di DIY Pekerjakan Difabel Masih Minim. Republika. 2018. Link : https://www.republika.co.id/berita/nasional/daerah/18/12/13/pjobi93 99-perusahaan-di-diy-pekerjakan-disabilitas-masih-minim 